\title{
Comparative Economic Analysis of Irrigated and Rainfed Spinach (Amaranthus cruentus) Production in Minna Metropolis, Niger State, Nigeria
}

\author{
${ }^{1}$ T.O. Obalola, and ${ }^{2}$ L. Tanko \\ 'Department of Agricultural Economics, Usmanu Danfodiyo University, P.M.B. 2346, Sokoto, \\ Nigeria \\ ${ }^{2}$ Department of Agricultural Economics and Extension Technology, Federal University of \\ Technology, P.M.B. 65, Minna, Niger State, Nigeria \\ E-mail: oyeyodeobalola@yahoo.com
}

\begin{abstract}
The study examined the comparative economic analysis of irrigated and rainfed spinach (Amaranthus cruentus) production in Minna metropolis, Niger State, Nigeria. Data were obtained from 120 randomly selected farmers using the purposive sampling technique. Production function model was used in the analysis of the data. The result showed that labour and farm size are the significant variables that influence spinach production output under the rainfed condition. On the irrigated scenario, labour, quantity of organic manure and quantity of improved seeds were the variables that influence the output of spinach production. It also revealed that there was over utilization of all the production inputs (i.e. labour, farm size, quantity of organic manure and the quantity of improved seeds) under consideration. Incorporating policy measures of efficient use of production inputs was suggested.
\end{abstract}

\section{INTRODUCTION}

Nigerian agriculture still maintained peasant oriented economy that was prominent in the preindependence period. Small scale farming constitutes the nucleus of Nigerian agriculture, producing about ninety percent of food and fibre for the Nigerian Population. In addition, it offers employment to about eighty percent of the population (Adewunmi and Omotesho, 2002). However, rain-fed agriculture plays a dominant role in crop production in Nigeria. In the northern part of the country, agriculture depends on both rainfall and irrigation. The nation is endowed with a number of surface and underground water sources that can be exploited to meet her irrigation requirements. Some of these sources have been developed by the River Basin Development Authorities, Agricultural Development Project (ADP), National Fadama Development Programme (NFDP) and other small scale private irrigation schemes which use other methods by harnessing of sub-surface water using wash bores or tube wells while the balance can be developed using rivers diversion modules, flood control structures and surface pumping, even if at a very low installed capacity. Nonetheless, there is a need for the nation to continue developing her irrigation potentials in order to meet the needs of the country's increasing population and consequently the rising food and fiber 
demand (Baba, 2010). The Food and Agriculture Organization (FAO, 1999) has warned that by the year 2025, Nigeria will no longer produce enough food to feed herself, solely from rainfed agriculture. According to Baba (2010), there is a problem faced by farmers who completely rely on rainfall since they cannot carryout year round farming. In addition, reliance entirely on rainfall alone is becoming even more precarious in view of climate change. In view of this fact, it is believed that Nigerian food problem demands an urgent development of the nation's water resources for irrigation. Increasing efficiency of resource use and productivity at the farm level, among many other factors, is one of the basics for sustainable agriculture (FAO, 1997). To achieve this increase, effort must be taken to examine the productive efficiency of farmers in the country using profit efficiency (Ogundari 2006).

According to Rahji and Omotesho (2006), the efficiency with which farmers use resources and technology available to them are imperative in Nigeria agricultural production since the main problem in the country revolves around low productivity. This has resulted in low farm income which has weakened the financial position of small holder farmers who produce most of the food crops in Nigeria, a condition that has led to poor funding of their economic activities.

It is against this background that this study attempt to provide answer to this specific research question:

1. Are the farmers efficient in the utilization of production resources?

\section{METHODOLOGY}

\section{Study area}

The study was carried out in Niger State, Nigeria. The State is located between latitudes $8^{\circ} 20^{\prime} \mathrm{N}$ and $11^{\circ} 30^{\prime} \mathrm{N}$ and longitudes $3^{\circ} 30^{\prime} \mathrm{E}$ and $7^{\circ} 20^{\prime} \mathrm{E}$. It shares boundaries with Kaduna State and Federal Capital Territory, Abuja in the North-East and South-East respectively, Kebbi and Zamfara in the North, Kwara and Kogi State in the South. (Niger State Ministry of Information, 2005). Niger State is estimated to have the population of 3,950,249 people while Minna city is estimated to have the population of 335,905 people (National Population Commission, 2006). With a total land area of $74,244 \mathrm{sq} . \mathrm{km}$, this gives the state a population density of about 33 per sq km; the lowest in the country (NPC, 2006). Minna generally experiences a moderate climate. The average temperature ranges from $24^{\circ} \mathrm{C}$ to $30^{\circ} \mathrm{C}$. In the month of April, the temperature rises to $30^{\circ} \mathrm{C}$ (Niger State Ministry of Information, 2005). Spinach (Amaranthus cruentus) is one of the leading green leafy vegetables in Nigeria. It takes an important place in the population diet because of its affordability and the nutrients it provides. Spinach is often grown and consumed in the rural, urban and per-urban area of Niger state. Growing vegetables is particularly suited for small-scale farmers and their families because of their limited resources (Robert 2003).

\section{Sampling technique}

The location was purposively sampled based on the preponderance of vegetable production in the area. Two districts namely; Chanchaga and Bosso were purposively selected in the area. Three 
villages namely: Chanchaga, Tunga Goro, Sauka ka huta, Tayi, Maikunkele, and Bosso Low cost respectively were randomly selected from each district. In all, a random selection of twenty farmers made up of irrigated and rainfed vegetable producers were selected from each of the villages making a total of 120 farmers from the metropolis.

\section{Analytical Technique}

The production function was used in the analysis of the data to compare the efficiency in resource utilization by samplerespondents in the production of the vegetable under irrigated and rainfed conditions.

The production function model was specified based on previous studies and was estimated econometrically. The model used was expressed in implicit form as:

$\mathrm{Y}=\mathrm{f}\left(\mathrm{X}_{1}, \mathrm{X}_{2}, \mathrm{X}_{3}, \mathrm{X}_{4}, \mathrm{X}_{5}, \mathrm{X}_{6}, \mathrm{X}_{7} \mathrm{e}\right)$

Where $Y=$ output of vegetable $(\mathrm{kg})$

$\mathrm{X}_{1}=$ labour (man days)

$X_{2}=$ farm size (hectares)

$\mathrm{X}_{3}=$ cost of fertilizer ( $\left.\mathrm{N}\right)$

$X_{4}=$ quantity of organic manure $(\mathrm{kg})$

$X_{5}=$ quantity of improved seeds $(\mathrm{kg})$

$\mathrm{X}_{6}=$ quantity of agrochemicals (in litres)

$\mathrm{X}_{7}=$ Depreciation on capital inputs (tools and equipment ) such as hoes, cutlasses, axes, machinery, interest on borrowed capital, rent $(\mathbb{A})$

$\mathrm{e}=$ error term

Four functional forms were fitted to the data and the lead equation was chosen based on statistical and econometric criteria such as the $R^{2}$ value, level of significance of the variables, consonance with apriori expectations, etc. The functional forms in explicit forms are as:

(i) Linear

$Y=b_{0}+b_{1} X_{1}+b_{2} X_{2}+b_{3} X_{3}+b_{4} X_{4}+b_{5} X_{5}+b_{6} X_{6}+b_{7} X_{7}+e$

(ii) Double log (Cobb-Douglas)

$\ln Y=\ln b_{0}+b_{1} \ln X_{1}+b_{2} \ln X_{2}+b_{3} \ln X_{3}+b_{4} \ln X_{4}+b_{5} \ln X_{5}+b_{6} \ln X_{6}+b_{7} \ln X_{7}+e$

(iii) Exponential

$\ln Y=b_{0}+b_{1} X_{1}+b_{2} X_{2}+b_{3} X_{3}+b_{4} X_{4}+b_{5} X_{5}+b_{6} X_{6}+b_{7} X_{7}+e$

(iv) Semi logarithmic

$Y=\operatorname{lnb} b_{0}+b_{1} \ln X_{1}+b_{2} \ln X_{2}+b_{3} \ln X_{3}+b_{4} \ln X_{4}+b_{5} \ln X_{5}+b_{6} \ln X_{6}+b_{7} \ln X_{7}+e$

\section{Efficiency of Resource Use}

An allocative index was computed to compare the efficiency in resource use by the two groups of farmers. This entails equating the marginal value product (MVP) of each input to its price or marginal factor cost (MFC). This is explicitly presented as:

$M V P=P_{x i}=M_{x i}$ 


$$
\begin{aligned}
& M V P_{x i}=M P P_{x i} P_{y} \\
& \mathrm{MPP}_{\mathrm{xi}}=\partial \mathrm{y} / \partial \mathrm{x}_{\mathrm{i}}-\mathrm{-}_{\mathrm{-}}
\end{aligned}
$$

Where; $M V P_{x i}$ is the marginal value product of the $i^{\text {th }}$ input, $P_{x i}$ is the unit price of the $i^{\text {it }}$ input, $M F C_{x i}$ is the marginal factor cost/acquisition cost of the $\mathrm{i}^{\text {ih }}$ input, $\mathrm{P}_{\mathrm{y}}$ is the price of unit of output, $\mathrm{MPP}_{\mathrm{xi}}$ is the marginal physical product of the $i^{\text {th }}$ input, $X_{i}$ is the mean quantity of $i^{\text {th }}$ input, and $Y$ is the mean weight of output. When $\mathrm{MVP}_{\mathrm{x}}>\mathrm{MFC}_{\mathrm{xi}}$ there is underutilization of resource $\mathrm{xi} ; \mathrm{MVP}_{\mathrm{xi}}<\mathrm{MFC}_{\mathrm{xi}}$ there is over utilization of resource xi; $\mathrm{MVP}_{\mathrm{xi}}=\mathrm{MFC}_{\mathrm{xi}}$ there is optimum utilization of resource xi (Mesike et al., 2009).

For the Linear functional form, the elasticity with respect to the production inputs was computed using the formula:

$E=\underset{\partial X i}{\partial Q} \cdot \mathrm{Xi}$

Where $=$ elasticity,$X_{i}=$ geometric mean of input $X_{i}, Q=$ geometric mean of the output. 
Obalola \& Tanko

\section{RESULTS AND DISCUSSION}

\section{Production Function Analysis}

A summary of the OLS estimates for Amaranthus cruentus farmers under rainfed condition is

Table 1: Summary of Regression Estimates of Factors Affecting the output vegetable farmers under rainfed condition

\begin{tabular}{|c|c|c|c|c|}
\hline Variables & Linear & Semi-log & Double- log & Exponential \\
\hline Constant & $\begin{array}{l}29.387 \\
(0.306)\end{array}$ & $\begin{array}{l}-535.188 \\
(-0.675)\end{array}$ & $\begin{array}{l}3.239^{*} \\
(1.867)\end{array}$ & $\begin{array}{l}4.997^{* * *} \\
(21.601)\end{array}$ \\
\hline (Labour) & $\begin{array}{l}10.633^{* * *} \\
(6.622)\end{array}$ & $\begin{array}{l}458.746^{\star * *} \\
(5.394)\end{array}$ & $\begin{array}{l}1.172^{\star * *} \\
(6.298)\end{array}$ & $\begin{array}{l}0.024^{* \star *} \\
(6.152)\end{array}$ \\
\hline (Farm size) & $\begin{array}{l}-11.082^{\star * *} \\
(-6.559)\end{array}$ & $\begin{array}{l}-16.838 \\
(-0.002)\end{array}$ & $\begin{array}{l}-0.035 \\
(-0.636)\end{array}$ & $\begin{array}{l}-0.009 \\
(-0.180)\end{array}$ \\
\hline (Fertilizer ${ }^{*}$ ) & $\begin{array}{l}-0.005 \\
(-0.351)\end{array}$ & $\begin{array}{l}-43.368 \\
(-0.477)\end{array}$ & $\begin{array}{l}-0.140 \\
(-0.705)\end{array}$ & $\begin{array}{l}-2.054 E-5 \\
(-0.625)\end{array}$ \\
\hline (Qty of Organic & -0.003 & 35.052 & 0.101 & $-7.585 E-6$ \\
\hline Manure in Kg) & $(-0.97)$ & (0.398) & (0.525) & $(-0.110)$ \\
\hline $\begin{array}{l}\text { (Qty of improved } \\
\text { seed in } \mathrm{Kg} \text { ) }\end{array}$ & $\begin{array}{l}46.794 \\
(1.179)\end{array}$ & $\begin{array}{l}34.679 \\
(0.376)\end{array}$ & $\begin{array}{l}-0.063 \\
(-0.314)\end{array}$ & $\begin{array}{l}0.065 \\
(0.682)\end{array}$ \\
\hline $\begin{array}{l}\text { (Qty of } \\
\text { agrochemical) }\end{array}$ & $\begin{array}{l}11.640 \\
(0.370)\end{array}$ & $\begin{array}{l}74.162 \\
(0.634)\end{array}$ & $\begin{array}{l}0.196 \\
(0.766)\end{array}$ & $\begin{array}{l}0.057 \\
(0.760)\end{array}$ \\
\hline (Capital inputs A) & $\begin{array}{l}-0.104 \\
(-0.971)\end{array}$ & $\begin{array}{l}-100.681 \\
(-1.015)\end{array}$ & $\begin{array}{l}-0.184 \\
(0.850)\end{array}$ & $\begin{array}{l}0.00 \\
(-0.608)\end{array}$ \\
\hline $\mathrm{R}^{2}$ & 0.664 & 0.621 & 0.643 & 0.610 \\
\hline $\mathrm{R}^{2}$-adjusted & 0.618 & 0.561 & 0.587 & 0.556 \\
\hline F-ratio & $14.410^{* * *}$ & $10.301^{* * *}$ & $11.339^{* * *}$ & $11.376^{* * *}$ \\
\hline
\end{tabular}

Source: Computed from survey data, 2012

Note: ${ }^{* * *}$ significant at $1 \%,{ }^{* *}$ Significant at $5 \%,{ }^{*}$ Significant at $10 \%$

Figures in parentheses are the respective t-ratios.

The result presented indicates that the lead equation is the linear functional form with $\mathrm{R}^{2}$ value of 0.664 and was therefore used for further discussion. This implies that about $66.4 \%$ of the variation in the output of Amaranthus cruentus farmers under rainfed condition is explained by the variables in the model. The F-ratio, 14.410 is statistically significant at $1 \%$ which indicates that the explanatory variables adequately explained the model. Out of the seven independent variables in the model, only two were statistically significant at explaining the output of the small holder farmers. The coefficient of labour is positive and statistically significant at $1 \%$. This indicates that labour input has a positive effect on the output of the farmers. The negative coefficient of farm size does not conform to a priori expectation. The negative sign shows an inverse relationship between farm size and spinach output. This means that if the farm size increases by one percent, spinach output will decrease by 11.082 percent. However, larger farm sizes coupled with good management practices should translate into increased output. 
Table 2: Regression Estimate of Factors Affecting the output of Vegetable farmers under irrigated condition.

\begin{tabular}{|c|c|c|c|c|}
\hline Variables & Linear & Semi-log & Double- log & Exponential \\
\hline Constant & $\begin{array}{l}6.730 \\
(0.019)\end{array}$ & $\begin{array}{l}617.915 \\
(0.0323)\end{array}$ & $\begin{array}{l}5.421 \\
(7.877)^{\star \star *}\end{array}$ & $\begin{array}{l}6.046 \\
(39.414)^{\star \star \star}\end{array}$ \\
\hline (Labour) & $\begin{array}{l}1.264 \\
(1.264)^{* *}\end{array}$ & $\begin{array}{l}832.275 \\
(4.619)^{* \star *}\end{array}$ & $\begin{array}{l}0.441 \\
(6.804)^{\star * *}\end{array}$ & $\begin{array}{l}0.001 \\
(2.305)^{\star *}\end{array}$ \\
\hline (Farm size) & $\begin{array}{l}231.435 \\
(1.657)\end{array}$ & $\begin{array}{l}19.278 \\
(0.083)\end{array}$ & $\begin{array}{l}0.047 \\
(0.562)\end{array}$ & $\begin{array}{l}0.170 \\
(2.809)^{\star * *}\end{array}$ \\
\hline (Fertilizer A) & $\begin{array}{l}0.029 \\
(1.058)\end{array}$ & $\begin{array}{l}103.902 \\
(0.508)\end{array}$ & $\begin{array}{l}-0.011 \\
(-0.152)\end{array}$ & $\begin{array}{l}7.629 \mathrm{E}-6 \\
(0.644)\end{array}$ \\
\hline $\begin{array}{l}\text { (Qty of Organic } \\
\text { Manure in Ka) }\end{array}$ & $\begin{array}{l}0.025 \\
(0.264)\end{array}$ & $\begin{array}{l}-350.338 \\
(-2.051)^{\star *}\end{array}$ & $\begin{array}{l}-0.058 \\
(-1.937)^{\star *}\end{array}$ & $\begin{array}{l}5.869 E-5 \\
(1.439)\end{array}$ \\
\hline $\begin{array}{l}\text { (Qty of improved } \\
\text { seed in } \mathrm{Kg} \text { ) }\end{array}$ & $\begin{array}{l}252.702 \\
(1.8590)^{*}\end{array}$ & $\begin{array}{l}595.636 \\
(2.050)^{\star \star}\end{array}$ & $\begin{array}{l}0.216 \\
(2.065)^{\star *}\end{array}$ & $\begin{array}{l}0.103 \\
(1.752)^{\star}\end{array}$ \\
\hline $\begin{array}{l}\text { (Qty of } \\
\text { agrochemical) }\end{array}$ & $\begin{array}{l}-25.229 \\
(-0.299)\end{array}$ & $\begin{array}{l}-334.999 \\
(-1.095)\end{array}$ & $\begin{array}{l}0.006 \\
(0.053)\end{array}$ & $\begin{array}{l}0.043 \\
(1.164)\end{array}$ \\
\hline (Capital inputs A) & $\begin{array}{l}-0.058 \\
(-0.317)\end{array}$ & $\begin{array}{l}-240.709 \\
(-1.008)\end{array}$ & $\begin{array}{l}-0.020 \\
(-0.233)\end{array}$ & $\begin{array}{l}6.298 E-5 \\
(0.788)\end{array}$ \\
\hline $\mathrm{R}^{2}$ & 0.403 & 0.542 & 0.750 & 0.575 \\
\hline $\mathrm{R}^{2}$-adjusted & 0.322 & 0.466 & 0.708 & 0.518 \\
\hline F-ratio & $5.008^{\star * *}$ & $7.114^{* * *}$ & $17.981^{* * *}$ & $10.052^{* * *}$ \\
\hline
\end{tabular}

\section{Source: Computed from survey data, 2012}

Note: ${ }^{* * *}$ significant at $1 \%,{ }^{* *}$ Significant at $5 \%,{ }^{*}$ Significant at $10 \%$

Figures in parentheses are the respective t-ratios.

Based on econometric criteria, the double-log functional form was selected as the lead equation. Three of the seven variables in the model were statistically significant at explaining the output of the farmers. They were labour, quantity of organic manure and quantity of improved seeds used. This could be attributed to the availability of cheap labour (family and hired) which might happen as a result of the inability of parents to train their wards as well as other dependents in school or on other businesses which make them readily available for agriculture. It could also be on the account of the farmers access to improved seeds and plentiful of organic manure. For a CobbDouglas production function, the estimated regression coefficients are direct elasticity. The coefficient of labour, quantity of Organic manure and quantity of improved seeds statistically significant at $1 \%$ and $5 \%$ respectively. 
Obalola \& Tanko

\section{Efficiency of resource use by the farmers}

The results of the resource use efficiency in Amaranthus cruentus production under rainfed condition are presented in Table 3.

Table 3: Allocative efficiency indices for rainfed condition

\begin{tabular}{lcccccc}
\hline Resources & Elasticity(b) & Py(N) & MVP(N) & MFC (A) & $\begin{array}{l}\text { Allocative efficiency } \\
\text { index (E) } \\
\text { E= MVP/ MFC }\end{array}$ & Decision \\
\hline Labour $\left(\mathrm{X}_{1}\right)$ & 1.10 & 20 & 22.0 & 700 & 0.0314 & $\begin{array}{c}\text { Over } \\
\text { utilized } \\
\text { Over } \\
\text { utilized }\end{array}$ \\
$\begin{array}{l}\text { Farm size } \\
\left(\mathrm{X}_{2}\right)\end{array}$ & -12.22 & 20 & -244.4 & 800 & -0.305 & \\
\hline
\end{tabular}

Source: Computed from field survey data, 2012

Note MVP = elasticity $(b)$ x price of unit of output $\left(P_{y}\right) ; P_{y}=N 20$.

The results indicate that all the resources were inefficiently utilized. In particular, the allocative efficiency indexes with respect to labour and farm size are 0.0314 and -0.305 respectively and are less than unity. This implies that labour input and farm size are over utilized.

A summary of the allocative efficiency indices of Amaranthus cruentus production under irrigated condition was computed and the results are presented in Table 4.

Table 4: Allocative efficiency indices for irrigated condition.

\begin{tabular}{lccccll}
\hline Resources & Elasticity(b) & Py(N) & MVP(N) & MFC (A) $\begin{array}{l}\text { Allocative } \\
\text { efficiency index } \\
\text { (E) } \\
\text { E= MVP/ MFC }\end{array}$ & Decision \\
\hline Labour $\left(X_{1}\right)$ & 0.441 & 30 & 13.230 & 1000 & 0.0132 & $\begin{array}{l}\text { Over } \\
\text { utilized } \\
\text { Over } \\
\text { utilized }\end{array}$ \\
$\begin{array}{l}\text { Quantity of } \\
\begin{array}{l}\text { Organic manure } \\
\left(X_{4}\right)\end{array}\end{array}$ & -0.058 & 30 & -1.740 & 40 & -0.0435 & \\
$\begin{array}{l}\text { Quantity of } \\
\begin{array}{l}\text { Improved seeds } \\
\left(X_{5}\right)\end{array}\end{array}$ & 0.216 & 30 & 6.480 & 50 & 0.1296 & $\begin{array}{l}\text { Over } \\
\text { utilized }\end{array}$ \\
\hline
\end{tabular}

\section{Source: Computed from field survey data, 2012}

Note: price of unit of output $=\mathrm{N} 30 / \mathrm{kg}$

For a Cobb-Douglas production function, the elasticity with respect to the production inputs is the estimated regression coefficients. The result reveals that all the resources were inefficiently utilized. In particular, the allocative efficiency index with respect to labour, quantity of organic manure and quantity of improved seed are $0.0132,-0.0435$ and 0.1296 which are less than unity. This implies that these inputs are over-utilized. The result supports Omotesho and Olawale (1991) hence less 
labour is to be used to improve resource use efficiency of labour. In this case the farmers are operating in stage III of the classical production function which is an irrational stage.

\section{CONCLUSION AND RECOMMENDATIONS}

The study shows that there is over utilization of the production inputs by the farmers. Both groups of farmers are operating in stage III of the classical production function. These are the limiting factors associated with the enterprises. To maximize output, the farmer should reduce the level of input employment so as to operate in stage II which is the rational stage of production. The results of the study therefore recommend policy measures of efficient use of production inputs by the farmers. Such could be policy directed towards making technology available and farmers' training through the extension agent to improve the resource use of the farmers.

\section{REFERENCES}

Adewunmi, M.O. and Omotesho, O.A (2002) "An Analysis of production objectives of small scale rural farming Household in Kwara State, Nigeria” Journal of Rural Development Korea. Rural Economic Institute, Korea. 25:201-21.

Baba, K..M. (2010). Irrigation Development and Food Security in Nigeria, Inaugural Lecture Series 15. Federal University of Technology, Minna, July $1^{\text {st }}, \mathrm{Pp} .60$.

FAO, (1999). Issues on urban agricultural retrieved $8^{\text {th }}$ December 2007 from FAO Website:http://www.fao.org/ag/magazine19901sp2.htm

Food and Agricultural Organization (FAO, 1997). Survey and Analysis of Aquaculture Development Research Priorities and Capabilities in Asia. FAO (Foodand Agricultural Organisation). Rome: Fisheries Circular,No. 930.

National Population Commission (NPC, 2006); the 2006 National Population Figure, Structure and Distribution.

Niger State Ministry of Information, 2005; Background information on Niger state, the history and location.

Ogundari, K. (2006). "Determinants of Profit Efficiency Among Small Scale Rice Farmers in Nigeria: AProfit Function Approach". Research Journal of Applied Sciences. 1(4): 116-122.

Omotesho, O.A. and Olawale, A.C. (1991): "Economics of Dry Season Vegetable Production along Asa river in llorin L.G.A. Kwara State": Journal of Rural Developmentin Nigeria4(1): 2429.

Rahji, M.A., and Omotesho, O.A. (2006). "Technical Inefficiency and Comparativeness in Production: The case of rice farmer in Niger State". Journal of Agriculture and FoodDevelopment. 8(1and 2): 